Article

\title{
High Temperature Water Gas Shift Reactivity of Novel Perovskite Catalysts
}

\author{
Janko Popovic ${ }^{1}$, Lorenz Lindenthal ${ }^{1}$, Raffael Rameshan ${ }^{1}$, Thomas Ruh ${ }^{1}$, Andreas Nenning ${ }^{2}{ }^{\circledR}$, \\ Stefan Löffler ${ }^{3}\left(\mathbb{D}\right.$, Alexander Karl Opitz ${ }^{2}$ and Christoph Rameshan ${ }^{1, *}$ \\ 1 TU Wien, Institute of Materials Chemistry, Getreidemarkt 9/165-PC, 1060 Vienna, Austria; \\ j.popovic@gmx.net (J.P.); lorenz.lindenthal@tuwien.ac.at (L.L.); raffael.rameshan@tuwien.ac.at (R.R.); \\ thomas.ruh@tuwien.ac.at (T.R.) \\ 2 TU Wien, Institute of Chemical Technologies and Analytics, Getreidemarkt 9/164-EC, 1060 Vienna, Austria; \\ andreas.nenning@tuwien.ac.at (A.N.); alexander.opitz@tuwien.ac.at (A.K.O.) \\ 3 TU Wien, USTEM, Wiedner Hauptstr. 8-10/E057-02, 1040 Vienna, Austria; stefan.loeffler@tuwien.ac.at \\ * Correspondence: christoph.rameshan@tuwien.ac.at; Tel.: +43-1-58801-165115
}

Received: 20 April 2020; Accepted: 20 May 2020; Published: 22 May 2020

check for updates

\begin{abstract}
High temperature water-gas shift (HT-WGS) is an industrially highly relevant reaction. Moreover, climate change and the resulting necessary search for sustainable energy sources are making WGS and reverse-WGS catalytic key reactions for synthetic fuel production. Hence, extensive research has been done to develop improved or novel catalysts. An extremely promising material class for novel highly active HT-WGS catalysts with superior thermal stability are perovskite-type oxides. With their large compositional flexibility, they enable new options for rational catalyst design. Particularly, both cation sites $\left(\mathrm{A}\right.$ and $\mathrm{B}$ in $\mathrm{ABO}_{3}$ ) can be doped with promoters or catalytically active elements. Additionally, B-site dopants are able to migrate to the surface under reducing conditions (a process called exsolution), forming catalytically active nanoparticles and creating an interface that can strongly boost catalytic performance. In this study, we varied A-site composition and B-site doping (Ni, Co), thus comparing six novel perovskites and testing them for their HT-WGS activity: $\mathrm{La}_{0.9} \mathrm{Ca}_{0.1} \mathrm{FeO}_{3-\delta}, \mathrm{La}_{0.6} \mathrm{Ca}_{0.4} \mathrm{FeO}_{3-\delta}, \mathrm{Nd}_{0.9} \mathrm{Ca}_{0.1} \mathrm{FeO}_{3-\delta}, \mathrm{Nd}_{0.6} \mathrm{Ca}_{0.4} \mathrm{FeO}_{3-\delta}, \mathrm{Nd}_{0.6} \mathrm{Ca}_{0.4} \mathrm{Fe}_{0.9} \mathrm{Ni}_{0.1} \mathrm{O}_{3-\delta}$ and $\mathrm{Nd}_{0.6} \mathrm{Ca}_{0.4} \mathrm{Fe}_{0.9} \mathrm{Co}_{0.1} \mathrm{O}_{3-\delta}$. Cobalt and Nickel doping resulted in the highest activity observed in our study, highlighting that doped perovskites are promising novel HT-WGS catalysts. The effect of the compositional variations is discussed considering the kinetics of the two partial reactions of WGS-CO oxidation and water splitting.
\end{abstract}

Keywords: water gas shift; perovskites; exsolution; nanoparticles; doping; catalyst design; tailored surfaces

\section{Introduction}

Water gas shift (WGS) is an industrially highly relevant catalytic reaction, with major applications for hydrogen production via steam reforming of methane [1,2] or from renewable sources like biomass and carbonaceous solid wastes [3-5], and for coal-to-liquid processes via Fischer-Tropsch synthesis [6]. Additionally, the reaction is involved in many processes as a partial reaction step, e.g., for ammonia or methanol synthesis. Especially due to the current need for renewable fuels, WGS is involved in many processes producing these fuels. Therefore, WGS has received considerable attention from researchers for a long time, primarily for developing more efficient and cheaper catalysts, both for high- and low-temperature WGS reactions [7-10]. The reaction

$$
\mathrm{CO}+\mathrm{H}_{2} \mathrm{O} \leftrightarrow \mathrm{H}_{2}+\mathrm{CO}_{2} \quad \Delta_{\mathrm{r}} \mathrm{H}_{298}=-42.09 \mathrm{~kJ} \mathrm{~mol}^{-1}
$$


is thermodynamically favoured at low temperatures, however, kinetics improves at higher temperatures (see also Figure S1, Supporting Info) [11]. Several groups have focused on the thermodynamic and kinetic aspects of the reaction $[12,13]$. Since there is virtually no change in volume from reactants to products, the reaction is not affected by pressure. The WGS reaction can be catalysed by both metals and metal oxides, and classical industrial reactions are typically run in two-step processes, with first a high-temperature step, and then a low-temperature step. The classical catalysts utilized for HT-WGS are iron-based [1], for example, $\mathrm{Fe}_{3} \mathrm{O}_{4} / \mathrm{Cr}_{2} \mathrm{O}_{3}$, with $\mathrm{Cr}_{2} \mathrm{O}_{3}$ used for stabilization to prevent catalyst sintering [14]. However, environmental concerns about chromium compounds have prompted the search for replacements for chromium in high-temperature catalysts [15]. Catalyst poisons for the iron-chromium catalyst are inorganic salts, boron, oils, phosphorus compounds, liquid water, and sulphur compounds [16]. For low-temperature WGS, the most widely used catalyst material is a mixture of $\mathrm{CuO}, \mathrm{ZnO}$, and $\mathrm{Al}_{2} \mathrm{O}_{3} / \mathrm{Cr}_{2} \mathrm{O}_{3}$ [17]. These catalysts have, however, the drawbacks of a lower thermal stability and their intolerance towards sulphur, halogens, and unsaturated hydrocarbons.

Due to the above-mentioned drawbacks of industrial WGS catalysts, extensive research is still being carried out to develop alternatives [18-21]. Promising materials are ceria- and noble-metal-based compounds [22], carbon-based WGS catalysts [23] or specially designed nanomaterials. For the latter, most of the recent research is focussed on fabricating nanostructured composite catalysts involving ceria supports along with transition or noble metals, with the aim of generating stable structures with extremely high surface areas [11]. A further interesting class of catalytically versatile and highly active materials are perovskites, which have been already tested for both low and high temperature WGS [24-26].

The general structure of perovskite type oxides is $\mathrm{ABO}_{3}$, with $\mathrm{A}$ and $\mathrm{B}$ being a large and small cation, respectively. The huge compositional flexibility of perovskite structures (different combinations of A and B cations), and the various options of doping A- and B-sites with promoting or catalytically highly active elements open up uncountable possibilities of rational catalyst design [24]. Furthermore, properties of many perovskites were extensively characterized by numerous groups, especially due to their broad application in catalysis, solid-state electrochemistry and fuel cell technology [27-33]. They exhibit excellent thermal stability (e.g., application temperatures in solid oxide fuel cells usually lie between 600 and $1000^{\circ} \mathrm{C}$ ), they are known to be resistant against catalyst poisons at higher operating temperatures, and catalyst regeneration is possible via redox cycling. Moreover, their improved thermal stability is making them resistant against temporary overheating in an industrial WGS process. Perovskites are beneficial for HT-WGS reactivity due to their reducibility and the resulting capability to provide lattice oxygen for the reaction (i.e., for the redox mechanism) $[34,35]$. Thereby, the created oxygen vacancies improve the water-splitting capability of the surface [36].

The advantages of perovskite-based HT-WGS catalysts outlined above were our motivation to synthesise novel materials and to study their catalytic performance in the temperature range from 300 to $600{ }^{\circ} \mathrm{C}$. The novel perovskite catalysts are $\mathrm{La}_{0.9} \mathrm{Ca}_{0.1} \mathrm{FeO}_{3-\delta}, \mathrm{La}_{0.6} \mathrm{Ca}_{0.4} \mathrm{FeO}_{3-\delta}, \mathrm{Nd}_{0.9} \mathrm{Ca}_{0.1} \mathrm{FeO}_{3-\delta}$, $\mathrm{Nd}_{0.6} \mathrm{Ca}_{0.4} \mathrm{FeO}_{3-\delta}, \mathrm{Nd}_{0.6} \mathrm{Ca}_{0.4} \mathrm{Fe}_{0.9} \mathrm{Ni}_{0.1} \mathrm{O}_{3-\delta}$ and $\mathrm{Nd}_{0.6} \mathrm{Ca}_{0.4} \mathrm{Fe}_{0.9} \mathrm{Co}_{0.1} \mathrm{O}_{3-\delta}$. The respective compositions were chosen in accordance with recent findings for highly active WGS materials. The catalytic activity of all novel materials was compared to and benchmarked against the commercially available perovskite $\mathrm{La}_{0.6} \mathrm{Sr}_{0.4} \mathrm{FeO}_{3-\delta}$ (LSF).

\section{Results and Discussions}

\subsection{Novel Perovskite Materials}

Six novel perovskite materials were synthesised for this study. A judicious choice of composition of the perovskite lattice was made (i.e., to use a ferrite perovskite as base material), enabling usage of the already present, catalytically active iron as B-site cation. Fe is well known as an active material for the high temperature WGS reaction $[37,38]$. With this, the support material already provides catalytic activity. Furthermore, the B-site can be doped with additional easily reducible catalytically active 
elements. In this study we used $10 \%$ of $\mathrm{Co}$ or $\mathrm{Ni}$, leading to catalyst materials that have an active base material with highly active elements embedded [39]. In reducing conditions and at a high temperature (e.g., HT-WGS conditions), these elements exsolve and migrate to the surface, where they form nanometre-sized particles, as we have shown in a previous study [24]. Moreover, numerous studies showed that the thereby exsolved particles are anchored and exhibit excellent morphological stability at a high temperature [40-42]. $\mathrm{Ni}$ is reported to promote methanation as a side reaction, but solid solutions of $\mathrm{Fe}$ and $\mathrm{Ni}$ in combination with a reducible oxide are reported to exhibit high activity and selectivity [15]. Co has also been studied as a WGS catalyst, e.g., in carbide-based catalysts [39].

For the A-site, $\mathrm{Nd}$ and $\mathrm{Ca}$ have been chosen with two different ratios: 6:4 and 9:1. Usually, La is one of the most common A-site elements. However, to avoid XPS peak overlap in future studies with dopant elements (especially Ni) $\mathrm{Nd}$ was used instead. Furthermore, rare earth materials are generally known for their catalytic activity, and both elements were reported in the literature to have a promotional effect on the WGS activity [2]. Acceptor-doping of the A-site with Ca introduces electronic defects (holes) and oxygen vacancies, which improves the electron and oxygen anion conductivities and reactivity of the material. Improved reactivity with Ca doping for WGS was previously shown by Maluf et al. for $\mathrm{La}_{2-x} \mathrm{Ca}_{x} \mathrm{CuO}_{4}$ [26]. In their study, a Ca content of $5 \%$ to $10 \%$ was reported to have the highest promotional effect. Furthermore, variation in the A-site dopant concentration (in our case Ca) allows additional fine-tuning of the lattice stability, and therefore the exsolution properties [43]. For the doped perovskites, we decided to increase the stability of the host lattice by increasing the amount of Ca A-site doping from $10 \%$ to $40 \%$. This results in a Goldschmidt tolerance factor closer to 1 , which means that the perovskite structure is closer to the ideal cubic structure [24,44]. At the same time, the electronic structure is also changed, with more $\mathrm{Fe}^{4+}$ present in the lattice, which raises the exsolution temperature [45]. With a more stable perovskite host lattice, it can be ensured that primarily dopant ions are exsolved into the particles decorating the surface under reducing conditions, and the Fe ions remain in the perovskite lattice [24].

To summarize, the novel perovskite materials $\mathrm{La}_{0.9} \mathrm{Ca}_{0.1} \mathrm{FeO}_{3-\delta}, \quad \mathrm{La}_{0.6} \mathrm{Ca}_{0.4} \mathrm{FeO}_{3-\delta}$, $\mathrm{Nd}_{0.9} \mathrm{Ca}_{0.1} \mathrm{FeO}_{3-\delta}, \mathrm{Nd}_{0.6} \mathrm{Ca}_{0.4} \mathrm{FeO}_{3-\delta}, \mathrm{Nd}_{0.6} \mathrm{Ca}_{0.4} \mathrm{Fe}_{0.9} \mathrm{Ni}_{0.1} \mathrm{O}_{3-\delta}$ and $\mathrm{Nd}_{0.6} \mathrm{Ca}_{0.4} \mathrm{Fe}_{0.9} \mathrm{Co}_{0.1} \mathrm{O}_{3-\delta}$ were investigated, particularly chosen for their high amount of catalytically active elements, thermochemical stability and capability of exsolution. Furthermore, the commercially available perovskite $\mathrm{La}_{0.6} \mathrm{Sr}_{0.4} \mathrm{FeO}_{3-\delta}$ (LSF) was tested as a reference material (unfortunately, benchmark experiments with a commercial Fe/Cr HT-WGS catalyst were not successful because of stability issues, particularly due to sintering and severe loss of BET surface area at high reaction temperatures). After synthesis, all novel perovskite powders were characterized with X-ray diffraction (XRD, cf. Figure 1) to check their crystal structure, and with BET (Brunauer-Emmett-Teller method) to obtain their surface area, Table $1[46,47]$. In Figure 1, stick patterns of reference structures with the same or similar composition are displayed as well (taken from the ICDD PDF-4 + 2019 database [48]; their PDF-Numbers are listed in Table 1).

Table 1. PDF-numbers of the reference structures used in Figure 1, BET surface areas of the different perovskite materials and average specific activities calculated for $\mathrm{CO}_{2}$ production during high temperature water-gas shift (HT-WGS) at $600^{\circ} \mathrm{C}$.

\begin{tabular}{cccc}
\hline Catalyst & PDF-Nr. & BET Area $\left(\mathbf{m}^{2} \mathbf{g}^{-1}\right)$ & $\begin{array}{c}\text { Specific Activity } \\
\left(10^{-7} \mathbf{m o l ~ m}^{-2} \mathbf{~ s}^{-1}\right)\end{array}$ \\
\hline $\mathrm{La}_{0.9} \mathrm{Ca}_{0.1} \mathrm{FeO}_{3-\delta}$ & $01-082-9272$ & 3.77 & 5.7 \\
$\mathrm{La}_{0.6} \mathrm{Ca}_{0.4} \mathrm{FeO}_{3-\delta}$ & $04-017-9772$ & 2.76 & 9.1 \\
$\mathrm{Nd}_{0.9} \mathrm{Ca}_{0.1} \mathrm{FeO}_{3-\delta}$ & $04-014-5430$ & 2.22 & 18.5 \\
$\mathrm{Nd}_{0.6} \mathrm{Ca}_{0.4} \mathrm{FeO}_{3-\delta}$ & - & 1.43 & 13.9 \\
$\mathrm{Nd}_{0.6} \mathrm{Ca}_{0.4} \mathrm{Fe}_{0.9} \mathrm{Ni}_{0.1} \mathrm{O}_{3-\delta}$ & - & 1.57 & 36.9 \\
$\mathrm{Nd}_{0.6} \mathrm{Ca}_{0.4} \mathrm{Fe}_{0.9} \mathrm{Co}_{0.1} \mathrm{O}_{3-\delta}$ & - & 1.24 & 28.4 \\
LSF & $04-007-6517$ & 5.07 & 8.5 \\
\hline
\end{tabular}




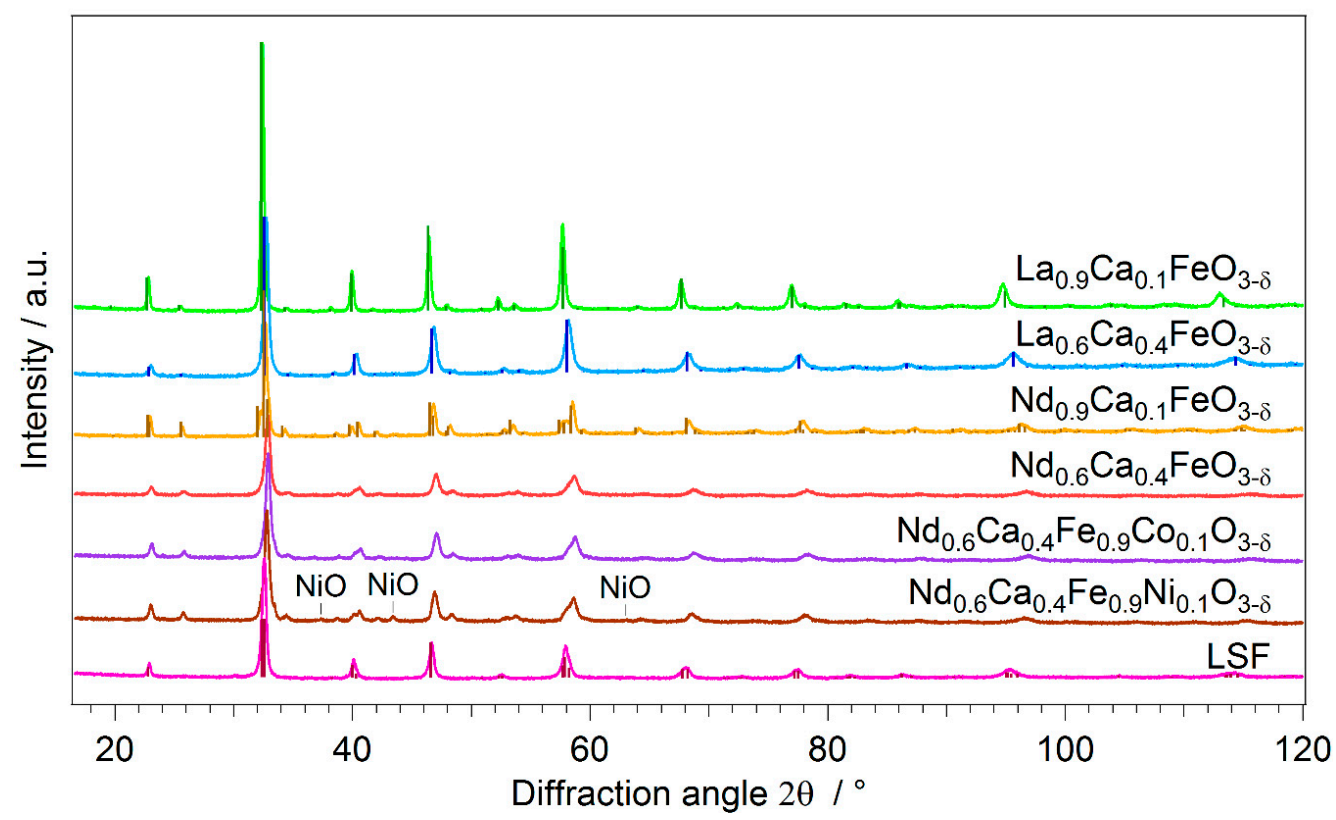

Figure 1. XRD patterns of the novel perovskites after synthesis and of $\mathrm{La}_{0.6} \mathrm{Sr}_{0.4} \mathrm{FeO}_{3-\delta}$ (LSF) as reference material. The bars are indicating the reflex positions of reference structures obtained from database entries for the respective materials. All perovskites were phase pure, except for the Ni-doped one, which showed trace amounts of $\mathrm{NiO}$.

A comparison of the measured patterns with these stick patterns shows that all materials were phase pure, except for the Ni-doped perovskite, proving that the syntheses were successful. For the $\mathrm{Ni}$-doped material, trace amounts of $\mathrm{NiO}$ were visible in the XRD pattern, indicating that not all $\mathrm{Ni}$ could be incorporated on the B-site of the perovskite lattice. In contrast, Co dopants were successfully integrated in the perovskite structure. Slight modifications in mean height width of the XRD patterns (Figure 1) suggest small differences in crystallinity between the materials. All materials were treated equally during synthesis (especially during the calcination step, cf. Section 3.1) to achieve a crystallinity as similar as possible, and thus achieve comparability of the catalysts. Therefore, the contribution of different crystallinity to varying exsolution behaviour and catalytic activity should be negligible. The BET analysis revealed surface areas between 1.13 and $5.07 \mathrm{~m}^{2} \mathrm{~g}^{-1}$ for the perovskites. These values are needed for the calculation of the specific activity of the catalysts (see Section 3.3).

\subsection{High Temperature Water Gas Shift Reactivity}

Prior to catalytic reaction, all novel perovskites were oxidized for $30 \mathrm{~min}$ at $600{ }^{\circ} \mathrm{C}$ in pure $\mathrm{O}_{2}$ (what is comparable to calcination at high temperatures). This guarantees identical initial conditions for all materials and helps for comparison of the results for the HT-WGS reaction. Following oxidation, all catalysts were cooled to $300{ }^{\circ} \mathrm{C}$ in $\mathrm{O}_{2}$, and then the gas atmosphere was changed to the reaction environment. For all experiments, the water vapour to $\mathrm{CO}$ ratio was 1:1 with $\mathrm{Ar}$ as carrier gas (i.e., Ar was bubbled through a humidifier to obtain the correct $\mathrm{H}_{2} \mathrm{O}$ partial pressure). The total flow was $12 \mathrm{~mL} \mathrm{~min}{ }^{-1}$. The perovskite powder samples were directly used without further dilution and held in position by a quartz wool bed. The amount of catalyst was chosen such that the thermodynamic equilibrium $\left(60 \%\right.$ conversion at $\left.600{ }^{\circ} \mathrm{C}\right)$ of the reaction was not reached. This is important, since WGS is an equilibrium reaction — at high temperatures and high conversions, the back reaction via reverse-WGS (r-WGS) starts being more and more dominant [49]. After changing to the reaction environment, the temperature was gradually raised to $600{ }^{\circ} \mathrm{C}$, with every temperature step of $100{ }^{\circ} \mathrm{C}$ being held for approximate $60 \mathrm{~min}$. During reaction, the catalytic reactivity was monitored via a micro-GC that was sampling continuously every 2 to $3 \mathrm{~min}$. 
Figure 2 displays the results for HT-WGS on the undoped perovskite $\mathrm{La}_{0.6} \mathrm{Ca}_{0.4} \mathrm{FeO}_{3-\delta}$. When changing to the reaction environment at $300{ }^{\circ} \mathrm{C}$, a short steep peak in $\mathrm{CO}_{2}$ formation and an accompanying drop in the $\mathrm{CO}$ signal is visible, followed by steady state reaction conditions (with a lower $\mathrm{CO}_{2}$ signal and a higher $\mathrm{CO}$ signal than during the initial phase). Similar behaviour can be observed when increasing the temperature to 400 and $500{ }^{\circ} \mathrm{C}$, respectively. When the reaction conditions become more reducing (either switching from $\mathrm{O}_{2}$ to $\mathrm{CO}+\mathrm{H}_{2} \mathrm{O}$, or increasing temperature), the amount of oxygen vacancies in the perovskite increases due to the reaction of $\mathrm{CO}$ with lattice oxygen, forming $\mathrm{CO}_{2}$. This leads to the initial $\mathrm{CO}_{2}$ production spikes and $\mathrm{CO}$ drops at the respective steps. The vacancy formation is reversible and temperature-dependent and the overall perovskite structure stays intact during this process.

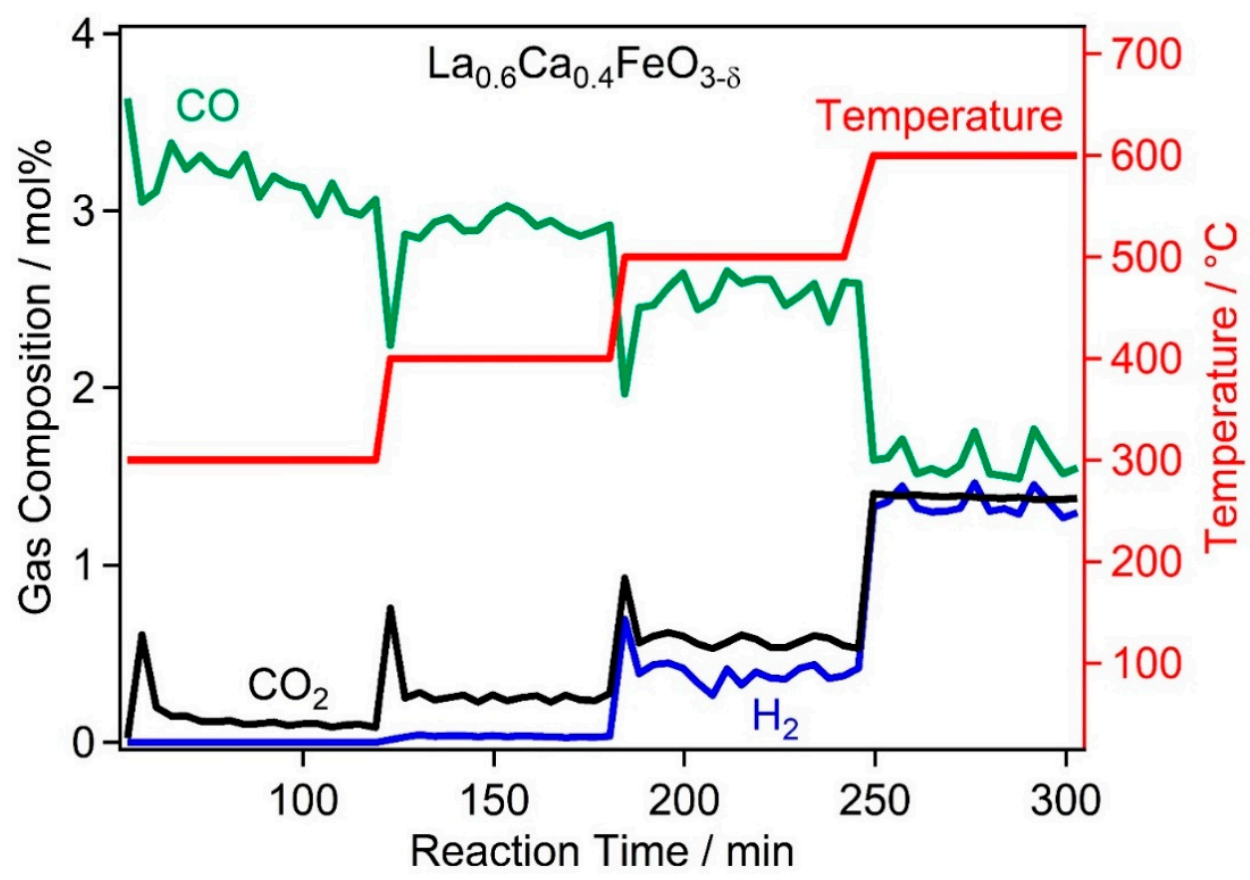

Figure 2. WGS reaction on $\mathrm{La}_{0.6} \mathrm{Ca}_{0.4} \mathrm{FeO}_{3-\delta}$. The reaction temperature was gradually increased from 300 to $600{ }^{\circ} \mathrm{C}$. Signals for $\mathrm{CO}$ (orange), $\mathrm{CO}_{2}$ (black) and $\mathrm{H}_{2}$ (blue) are displayed. During the initial temperature steps, short spikes in the $\mathrm{CO}_{2}$ production are visible, originating from lattice oxygen reacting with $\mathrm{CO}$.

Figure 3 proves the reactivity of a perovskite (exemplary for $\mathrm{Nd}_{0.9} \mathrm{Ca}_{0.1} \mathrm{FeO}_{3-\delta}$ ) by a simple experiment, where in the fed gas only $\mathrm{CO}$ was present (no water, $0.70 \mathrm{~mL} \mathrm{~min}^{-1} \mathrm{CO}$ and $11.75 \mathrm{~mL}$ $\mathrm{min}^{-1} \mathrm{Ar}$ as carrier gas). After oxidation, the perovskite was exposed to the dry reaction atmosphere at $300{ }^{\circ} \mathrm{C}$. Immediately, a strong increase in the $\mathrm{CO}_{2}$ production could be seen that was dropping rapidly. As mentioned, this is because lattice oxygen is reacting with $\mathrm{CO}$. When increasing the reaction temperature to $600{ }^{\circ} \mathrm{C}$, the same effect could be seen again. As the starting point was a fully oxidized perovskite, the lattice acts as an oxygen reservoir until an equilibrium state is reached (i.e., no further reduction of the material is possible at the specific reaction conditions). With a higher temperature, the equilibrium oxygen vacancy concentration and the ion mobility increase (i.e., more oxygen vacancies can be formed, and faster) [50]. This explains why the $\mathrm{CO}_{2}$ production spikes occur repeatedly when increasing the temperature (both in Figures 2 and 3). However, for real WGS and higher temperatures, this effect diminishes, as the reducibility of the perovskite reaches a limit and water vapour in the fed gas is re-oxidizing oxygen vacancies more effectively. Similar observations were reported by Sun et al. for $\mathrm{La}_{0.9-x} \mathrm{Ce}_{x} \mathrm{FeO}_{3-\delta}$ perovskite catalysts, where Ce improves the reducibility of the perovskite lattice, thus enhancing catalytic activity [25]. 


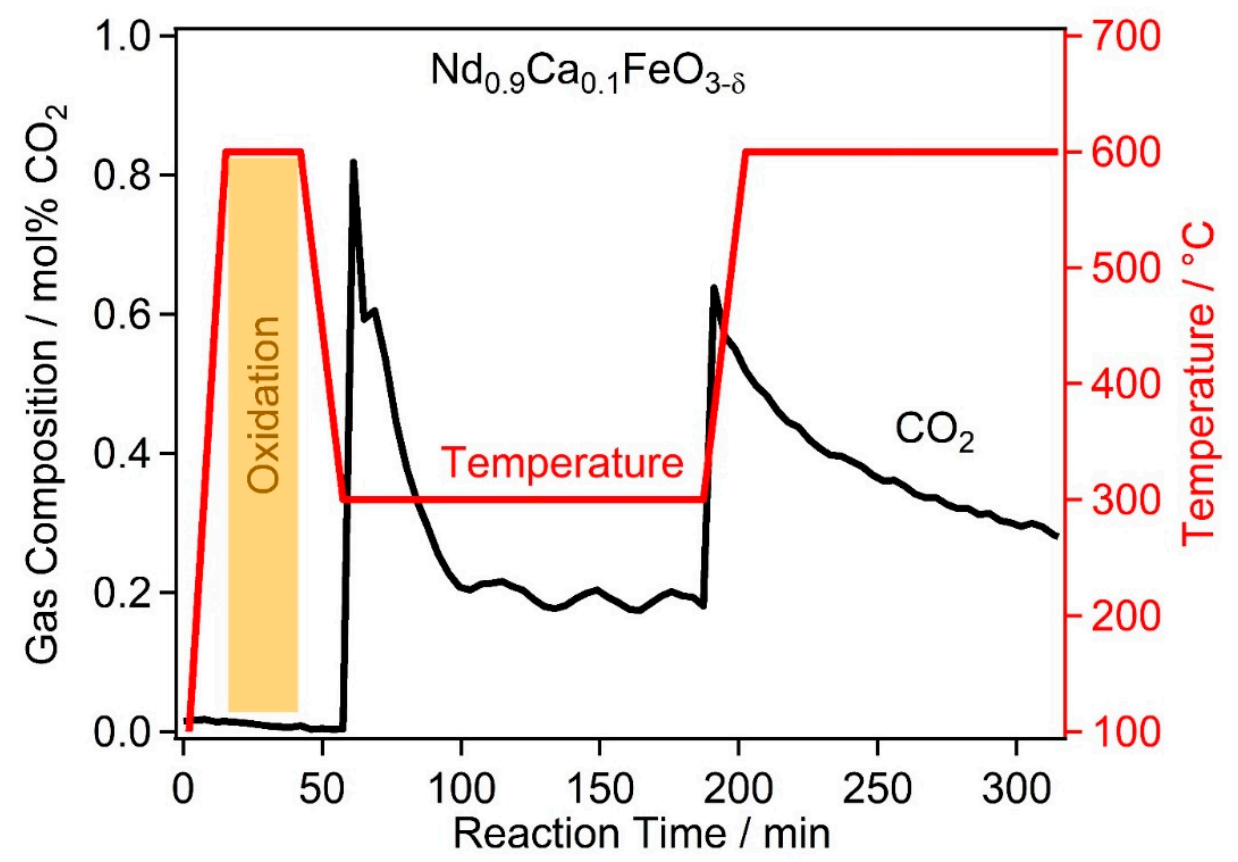

Figure 3. Reaction of pure $\mathrm{CO}$ with the $\mathrm{Nd}_{0.9} \mathrm{Ca}_{0.1} \mathrm{FeO}_{3-\delta}$ perovskite. After oxidation at $600{ }^{\circ} \mathrm{C}$ and cooling to $300{ }^{\circ} \mathrm{C}$, the gas flow was switched to $\mathrm{CO} / \mathrm{Ar}\left(0.70\right.$ and $11.3 \mathrm{~mL} \mathrm{~min}^{-1}$, respectively). The conditions were held for $2 \mathrm{~h}$ and then the temperature was raised from 300 to $600{ }^{\circ} \mathrm{C}$. Increased formation of $\mathrm{CO}_{2}$ could be observed at the beginning of each phase (both after switching the atmosphere and after increasing the temperature), which was then dropping rapidly.

The highest reactivity of the material $\mathrm{La}_{0.6} \mathrm{Ca}_{0.4} \mathrm{FeO}_{3-\delta}$ was reached at $600^{\circ} \mathrm{C}$ with a $\mathrm{CO}$ conversion of around $46 \%$ (thermodynamic limit $60 \%$ ). $\mathrm{H}_{2}$ formation started at $400{ }^{\circ} \mathrm{C}$, but at a lower level than $\mathrm{CO}_{2}$ formation. Maybe the lattice oxygen content is slowly changing isothermally, which leads to increased $\mathrm{CO}_{2}$ production. This would mean that equilibration of the perovskite stoichiometry is (after a first quick convergence, resulting in the $\mathrm{CO}_{2}$ spikes) a relatively slow process at 300 to 400 ${ }^{\circ} \mathrm{C}$. This hypothesis is supported by Figure 3, where the initial high $\mathrm{CO}_{2}$ formation rate was, after a sudden drop, slowly decreasing over time and did not fully vanish. At $600{ }^{\circ} \mathrm{C}, \mathrm{H}_{2}$ and $\mathrm{CO}_{2}$ production reach the expected stoichiometric ratio of $1: 1\left(\mathrm{H}_{2}: \mathrm{CO}_{2}\right)$, indicating that the oxygen stoichiometry of the perovskite has reached its equilibrium due to increased kinetics. The reason for this is that, at higher reaction temperatures, the water-splitting kinetics of the perovskite strongly improve [51], providing as much oxygen for the redox mechanism as is consumed for $\mathrm{CO}_{2}$ formation [34].

All other novel perovskites (including LSF as a reference) were tested in the same way. Figure 4 summarizes the results of these measurements. To be able to directly compare our different materials, the $\mathrm{CO}_{2}$ formation rate is displayed as area-specific activity in $\mathrm{mol} \mathrm{m}^{-2} \mathrm{~s}^{-1}$. In order to get these values, catalytic activity was normalized by active surface area of the respective perovskites; see Section 3.3 for details. As perovskites exhibit a rich and highly dynamic surface chemistry, which is strongly dependent on gas environment and reaction temperature, it was decided to use a specific activity instead of a turnover frequency (TOF). The average specific activity at $600{ }^{\circ} \mathrm{C}$ is given in Table 1 for all materials.

The two La-based and B-site undoped perovskites $\mathrm{La}_{0.9} \mathrm{Ca}_{0.1} \mathrm{FeO}_{3-\delta}$ and $\mathrm{La}_{0.6} \mathrm{Ca}_{0.4} \mathrm{FeO}_{3-\delta}$ showed the lowest activity for the HT-WGS reaction, which was comparable to commercial LSF at $600{ }^{\circ} \mathrm{C}$.

Variation of A-site composition by increasing the Ca concentration increased the reactivity at $600{ }^{\circ} \mathrm{C}$ slightly. This is in contrast to previous studies that reported better reactivity with lower Ca content [26]. When exchanging La with $\mathrm{Nd}$, reactivity of the perovskites for HT-WGS increases significantly (cf. Table 1) - by a factor of about 3 for $10 \%$ Ca doping. For $\mathrm{Nd}_{0.9} \mathrm{Ca}_{0.1} \mathrm{FeO}_{3-\delta}$ and $\mathrm{Nd}_{0.6} \mathrm{Ca}_{0.4} \mathrm{FeO}_{3-\delta}$ an opposite trend with respect to the $\mathrm{Ca}$ content was found. With lower $\mathrm{Ca}$ content 
the reactivity was higher, which is in line with previous studies [26]. At $400{ }^{\circ} \mathrm{C}, \mathrm{Nd}_{0.9} \mathrm{Ca}_{0.1} \mathrm{FeO}_{3-\delta}$ even had the highest activity of all tested undoped materials. However, while there was still a strong increase in activity when changing to $500{ }^{\circ} \mathrm{C}$, increasing reaction temperature from 500 to $600{ }^{\circ} \mathrm{C}$ did not significantly increase the reactivity anymore (note: thermodynamic limitations could be excluded, as conversion was at roughly $40 \%$, while the thermodynamic limit is at $60 \%$ at $600{ }^{\circ} \mathrm{C}$ ). A qualitatively similar behaviour can be observed for $\mathrm{La}_{0.9} \mathrm{Ca}_{0.1} \mathrm{FeO}_{3-\delta}$, while both $\mathrm{La}_{0.6} \mathrm{Ca}_{0.4} \mathrm{FeO}_{3-\delta}$ and $\mathrm{Nd}_{0.6} \mathrm{Ca}_{0.4} \mathrm{FeO}_{3-\delta}$ have a stronger reactivity increase from 500 to $600{ }^{\circ} \mathrm{C}$ than from 400 to $500{ }^{\circ} \mathrm{C}$.

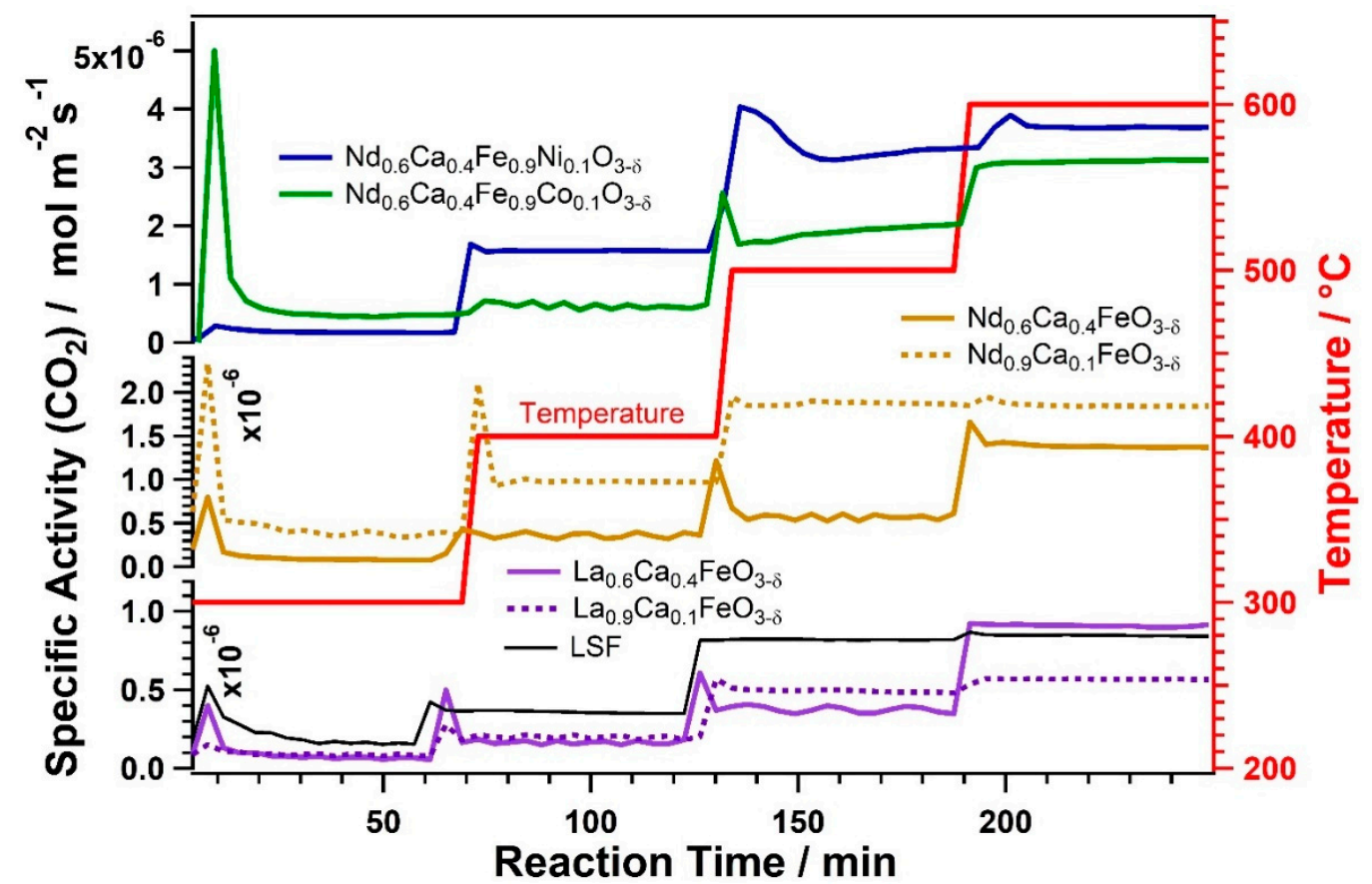

Figure 4. Comparison of HT-WGS activity of the novel perovskites. For this, the $\mathrm{CO}_{2}$ formation rate is given as surface specific activity in $\mathrm{mol} \mathrm{m}^{-2} \mathrm{~s}^{-1}$. For comparison, the reactivity of LSF is shown as well (black line). The reaction environment consisted of a 1:1 mixture of $\mathrm{H}_{2} \mathrm{O}$ and $\mathrm{CO}$, and temperature was increased gradually from 300 to $600{ }^{\circ} \mathrm{C}$. The Co- and Ni-doped perovskites were the most active materials at the highest reaction temperature.

A possible reason may be related to a difference in the oxygen vacancy formation energies, depending on the amount of Ca doping (10\% vs. $40 \%$ ). Thus, the perovskites with lower Ca doping would reach their limit of formed oxygen vacancies, which play an essential role in WGS activity (cf. Section 2.4), faster and already at a lower temperature (i.e., $500{ }^{\circ} \mathrm{C}$ ) than those with more Ca. After reaching this limit, there is no more strong increase in activity. On the other hand, the perovskites with higher Ca doping can still increase the amount of oxygen vacancies and the WGS reactivity at $600{ }^{\circ} \mathrm{C}$. To really understand this different behaviour, further in situ studies would be needed.

This reducing behaviour is also supported by the occurrence of the initial $\mathrm{CO}_{2}$ formation spikes previously discussed, which are visible in Figure 4 as well. However, their interpretation has to be done carefully, as, due to the sampling interval of 2 to $3 \mathrm{~min}$, the peaks (especially small ones) might not be fully resolved. Nevertheless, for $\mathrm{Nd}_{0.9} \mathrm{Ca}_{0.1} \mathrm{FeO}_{3-\delta}$ a strong initial spike can be observed after increasing the reaction temperature to $400{ }^{\circ} \mathrm{C}$. This indicates the easy reducibility of the material at these reaction conditions, resulting in a high amount of oxygen vacancies and enhanced WGS reactivity [34]. These effects are further discussed in Section 2.4.

Results for the Ni-doped perovskite $\mathrm{Nd}_{0.6} \mathrm{Ca}_{0.4} \mathrm{Fe}_{0.9} \mathrm{Ni}_{0.1} \mathrm{O}_{3-\delta}$ in Figure 4 (blue curve) show that doping increased the reactivity towards $\mathrm{CO}_{2}$ compared to the similar undoped material $\left(\mathrm{Nd}_{0.6} \mathrm{Ca}_{0.4} \mathrm{FeO}_{3-\delta}\right)$. In contrast to reports in the literature, we did not observe any methanation as a side reaction [11,15]. For Co-doped $\mathrm{Nd}_{0.6} \mathrm{Ca}_{0.4} \mathrm{Fe}_{0.9} \mathrm{Co}_{0.1} \mathrm{O}_{3-\delta}$ a huge initial $\mathrm{CO}_{2}$ peak was visible 
when changing to reaction conditions at $300^{\circ} \mathrm{C}$. Again, this is interpreted as an indication of the easier reducibility of the material compared to the other perovskites, and therefore the easier formation of oxygen vacancies. This interpretation is also in accordance with the defect chemical behaviour of the similar material family $\mathrm{La}_{1-x} \mathrm{Sr}_{x} \mathrm{Co}_{1-y} \mathrm{Fe}_{\mathrm{y}} \mathrm{O}_{3-\delta}$ (typically used as solid oxide fuel cell cathodes) where the reducibility is also increased by cobalt addition [52]. Generally, weakly bound oxygen atoms in highly reducible materials (i.e., materials with a higher oxygen storage capacity) have been reported in the literature to be critical to the performance efficiency of the WGS reaction [53].

While for the undoped materials the activity is stable after the first initial spike in a step, both the $\mathrm{Ni}$ - and the Co-doped perovskite show slowly increasing reactivity after the spike at $500{ }^{\circ} \mathrm{C}$. This can be attributed to the formation of catalytically active nanoparticles (cf. Section 2.4). This process is slower than the formation of oxygen vacancies and takes place during the whole temperature step. For $\mathrm{Nd}_{0.6} \mathrm{Ca}_{0.4} \mathrm{Fe}_{0.9} \mathrm{Co}_{0.1} \mathrm{O}_{3-\delta}$, it even continues at $600{ }^{\circ} \mathrm{C}$, visible by the slow signal increase.

At $600{ }^{\circ} \mathrm{C}$, Ni-doped $\mathrm{Nd}_{0.6} \mathrm{Ca}_{0.4} \mathrm{Fe}_{0.9} \mathrm{Ni}_{0.1} \mathrm{O}_{3-\delta}$ exhibited the best reactivity of all novel perovskites with a specific activity of $3.69 \cdot 10^{-6} \mathrm{~mol} \mathrm{~m}^{-2} \mathrm{~s}^{-1}$, followed by the Co-doped perovskite with a specific activity of $2.84 \cdot 10^{-6} \mathrm{~mol} \mathrm{~m}^{-2} \mathrm{~s}^{-1}$. We also checked for all tested materials if any side reactions were occurring (e.g., the formation of methane) but only the expected reaction educts and products could be detected.

\subsection{Electron Microscopy}

Before and after HT-WGS reaction, scanning electron microscopy (SEM) images of the used catalysts were recorded (see also Supporting Information, Figure S2). Whereas undoped $\mathrm{Nd}_{0.9} \mathrm{Ca}_{0.1} \mathrm{FeO}_{3-\delta}$ still retained its crystalline surface structure after reaction, cf. Figure $5 b$, the surface of the doped perovskite $\mathrm{Nd}_{0.6} \mathrm{Ca}_{0.4} \mathrm{Fe}_{0.9} \mathrm{Co}_{0.1} \mathrm{O}_{3-\delta}$ changed, cf. Figure $5 \mathrm{a}$. The formation of well dispersed nanoparticles during the catalytic reaction could be observed (i.e., by exsolution) [42,54]. The particle size ranges from 30 to $65 \mathrm{~nm}$, and during reaction conditions the particles are most probably composed of metallic or oxidized cobalt, owing to the easy reducibility of the Co dopant element and its resulting preferential exsolution. Unfortunately, the particles were too small for an elemental analysis with energy dispersive X-ray spectroscopy (EDX), but in own previous work on reverse WGS on the same material [24] (including in-situ XRD measurements), formation of cobalt oxide ( $\mathrm{CoO})$ was found.
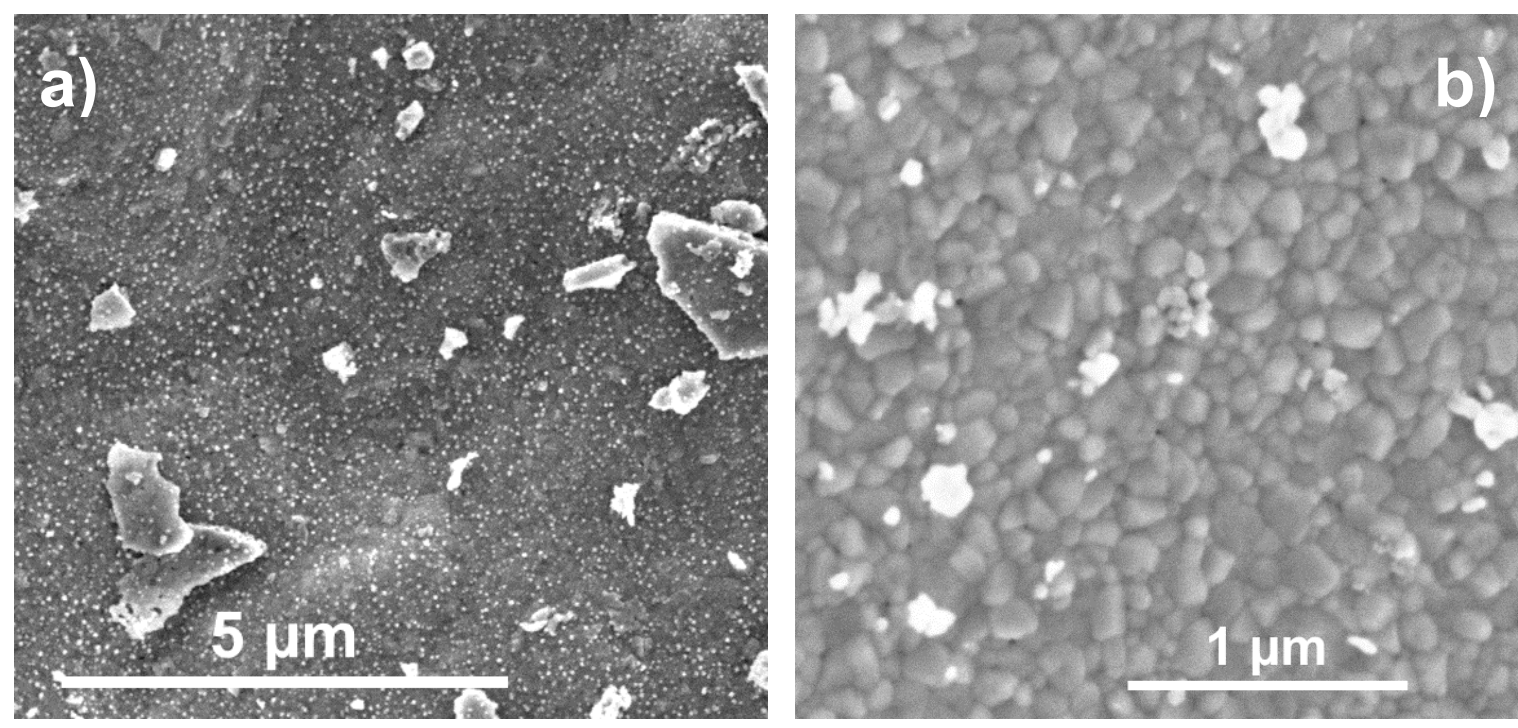

Figure 5. SEM image of (a) $\mathrm{Nd}_{0.6} \mathrm{Ca}_{0.4} \mathrm{Fe}_{0.9} \mathrm{Co}_{0.1} \mathrm{O}_{3-\delta}$ and (b) $\mathrm{Nd}_{0.9} \mathrm{Ca}_{0.1} \mathrm{FeO}_{3-\delta}$ after HT-WGS reaction. Formation of finely dispersed nanoparticles on the surface is visible in (a). The average size of the nanoparticles is between 30 and $65 \mathrm{~nm}$. In image (b), only the crystallite structure of the perovskite is visible, but no exsolved nanoparticles can be observed for the undoped material. 
Nevertheless, since the experimental system was defined in a way so as to not reach thermodynamic equilibrium, the redox state of the particles may also be different in the present case. Furthermore, no sintering of the nanoparticles was observed at a high reaction temperature.

\subsection{Discussion of WGS Activity of the Catalyst Materials}

As shown in the results above, the variation oin catalyst composition resulted in a relatively complex change in the catalytic behaviour. While on some materials, only the WGS shift reactivity was improved, others showed an increase in the $\mathrm{CO}_{2}$ spike at the beginning of the temperature plateaus, often coinciding with an enhanced WGS reaction rate. To interpret this, we need to have a closer look at the reactions occurring on the perovskite catalysts.

As already mentioned above, the spike is a result of $\mathrm{CO}$ oxidation by the pre-oxidised perovskite catalyst via the reaction

$$
\mathrm{CO}+\mathrm{O}_{\mathrm{O}}^{\times}+2 \mathrm{~h} \rightarrow \mathrm{CO}_{2}+\mathrm{V}_{\mathrm{O}}
$$

where $\mathrm{O}_{\mathrm{O}}^{\times}, \mathrm{h}$, and $\mathrm{V}_{\mathrm{O}}$ (in Kröger-Vink notation) denote regular lattice oxygen, electron hole, and oxygen vacancy, respectively. Assuming the WGS reaction on the perovskite oxides to proceed via a redox mechanism [1], Equation (2) is also the first step of WGS. In this case, the WGS reaction is then completed by refilling the lattice oxygen (i.e., re-oxidising the perovskite) by splitting water

$$
\mathrm{H}_{2} \mathrm{O}+\mathrm{V}_{\mathrm{O}} \rightarrow \mathrm{H}_{2}+\mathrm{O}_{\mathrm{O}}^{\times}+2 \mathrm{~h}
$$

Previous studies indicate that Equation (2) proceeds entirely on the oxide surface with an electron transfer to the perovskite; the presence of metal particles has virtually no effect on the CO oxidation and $\mathrm{CO}_{2}$ reduction reaction rate on perovskite-type oxides [54,55]. Improving the reducibility of the perovskite-e.g., by introducing elements allowing an easier valence change and thus easier electron transfer-is expected to enhance the reaction rate of Equation (2). The equilibrium reaction rate of water splitting on the oxide surface (Equation (3)) is somewhat higher than the rate of Equation (2), but of the same order of magnitude [56,57]. However, in contrast to Equation (2) the water-splitting reaction can be enhanced by the presence of metallic particles on the perovskite surface, which allow circumventing its rate-limiting step [51,58-60].

Considering these facts, the following explanation is suggested for the observed effects of compositional variation in the perovskite-type catalysts: on the oxide surface, both reactions (Equations (2) and (3)) limit the rate of WGS to a similar extent [56,57]. Changing the composition from the La-based materials to the Nd-containing ones increased the redox activity of the material.

Probably, either $\mathrm{Nd}$ has higher redox activity (mixed $2+/ 3+$ surface valence) compared to La or helps in mitigating the surface segregation of Ca [61]. Consequently, the rate of Equation (2) is enhanced, which results in a larger $\mathrm{CO}_{2}$ spike and enhanced WGS activity (see Figure 4). Similarly, Equation (3) may be affected, but since here the recombination of adsorbed hydrogen is discussed to be involved in the rate determining step, we expect only a rather small (if any) effect on Equation (3).

Doping the B-site with Co had a large effect on both the $\mathrm{CO}_{2}$ spike and the WGS activity, which can be explained by an enhanced reaction rate of Equation (2), since especially Co is known to provide a very high redox activity in perovskites [62,63]. In addition, the existence of exsolved particles on the surface was proved with SEM, which-especially if present in metallic form-may catalyse Equation (3). This is supported by the increase in the $\mathrm{CO}_{2}$ signal during the $500^{\circ} \mathrm{C}$ step, a temperature where we expect exsolution to occur. Since the oxidation state of these exsolved particles is not clarified yet, further (in-situ) experiments are needed to definitely answer this question.

The doping with Ni greatly increased the WGS activity, but without affecting the $\mathrm{CO}_{2}$ spike at the beginning of the temperature steps (compare $\mathrm{Nd}_{0.6} \mathrm{Ca}_{0.4} \mathrm{FeO}_{3-\delta}$ and $\mathrm{Nd}_{0.6} \mathrm{Ca}_{0.4} \mathrm{Fe}_{0.9} \mathrm{Ni}_{0.1} \mathrm{O}_{3-\delta}$ in Figure 4). Since $\mathrm{Ni}$ is not as redox active in the oxide as $\mathrm{Co}$ (Ni is expected to only be stable in oxidation state of +2 in the used reaction atmosphere), the enhancement of the WGS activity cannot be caused by increasing the rate of Equation (2) - thus $\mathrm{Ni}$ doping is not causing a larger $\mathrm{CO}_{2}$ spike. Instead, 
Ni mainly affects the WGS reaction by enhancing the water-splitting reaction (Equation (3)) upon providing metallic (exsolved) particles at the perovskite surface [64]. As the Ni-doped material was not phase pure, the particles were probably partly (or maybe even fully) not exsolved, but just a result of the reduced $\mathrm{NiO}$, migrating to the surface. This process ought to be faster than pure exsolution as in $\mathrm{Nd}_{0.6} \mathrm{Ca}_{0.4} \mathrm{Fe}_{0.9} \mathrm{Co}_{0.1} \mathrm{O}_{3-\delta}$, explaining why $\mathrm{Nd}_{0.6} \mathrm{Ca}_{0.4} \mathrm{Fe}_{0.9} \mathrm{Ni}_{0.1} \mathrm{O}_{3-\delta}$ has the largest activity increase from 400 to $500{ }^{\circ} \mathrm{C}$ and only a smaller one from 500 to $600{ }^{\circ} \mathrm{C}$. On the other hand, the Co-doped material still shows a large increase at the last step, due to improved exsolution at a higher temperature.

From these thoughts, a strategy to further enhancing WGS activity of perovskite-type catalysts can be deduced. For maximising the WGS reaction rate, both reactions-Equations (2) and (3)-need to be fast. This can be achieved by a redox active perovskite oxide and simultaneously providing metallic particles at the surface (e.g., Ni). Testing this hypothesis will be performed in a forthcoming study. As can be seen in Figure 4 and Table 1, especially the latter effect greatly enhanced the catalytic activity of the materials. Therefore, considerable attention will be given to the exsolution process.

\subsection{Stability of Novel Perovskite Catalysts}

To obtain initial insights into reaction stability of the novel perovskites, isothermal reactions were performed at $600{ }^{\circ} \mathrm{C}$. This high temperature was chosen to check if any rapid deactivation occurs. Here, the results for $\mathrm{Nd}_{0.6} \mathrm{Ca}_{0.4} \mathrm{FeO}_{3-\delta}$ and Co-doped $\mathrm{Nd}_{0.6} \mathrm{Ca}_{0.4} \mathrm{Fe}_{0.9} \mathrm{Co}_{0.1} \mathrm{O}_{3-\delta}$ are displayed. Results for all other materials can be found in the Supporting Information (Figures S3-S7).

For the experiments, all materials were first oxidized for $30 \mathrm{~min}$ in pure $\mathrm{O}_{2}$ at $600{ }^{\circ} \mathrm{C}$ to have a defined starting point. During the next steps, the catalysts were cooled to $300{ }^{\circ} \mathrm{C}$ in $\mathrm{O}_{2}$, and the gas atmosphere was switched to the reaction environment. Afterwards, the reaction temperature was rapidly increased to $600{ }^{\circ} \mathrm{C}$. This was done in order to be able to observe any strong initial activation/deactivation phenomena, which we did not find. In summary, all novel materials showed quite stable reactivity within the investigated timeframe. The results for $\mathrm{Nd}_{0.6} \mathrm{Ca}_{0.4} \mathrm{FeO}_{3-\delta}$ are displayed in Figure 6.

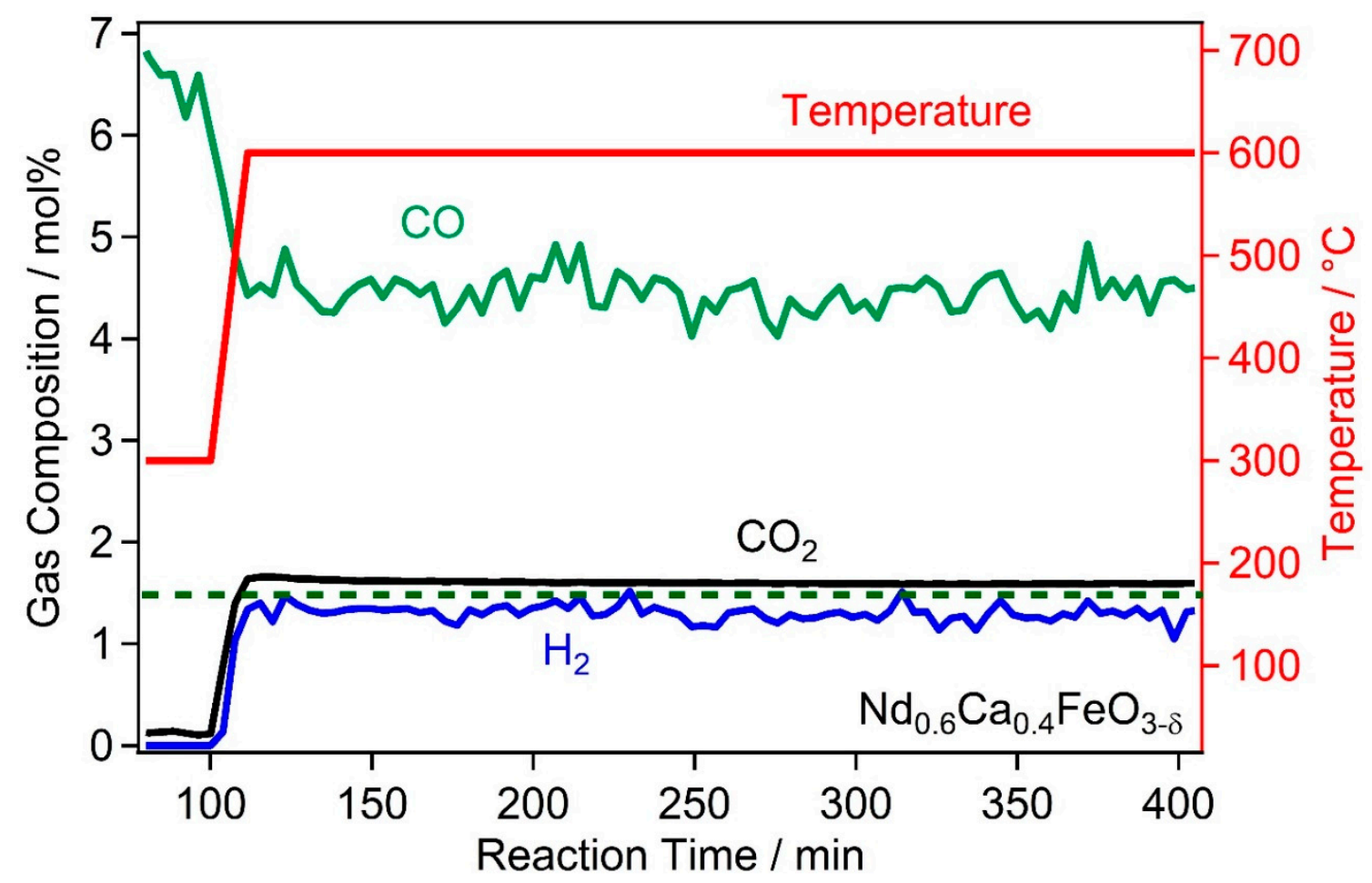

Figure 6. Isothermal HT-WGS reaction at $600{ }^{\circ} \mathrm{C}$ for $\mathrm{Nd}_{0.6} \mathrm{Ca}_{0.4} \mathrm{FeO}_{3-\delta}$. The dashed line serves as a horizontal guide for the eye. During the duration of the reaction (about $5 \mathrm{~h}$ ), the catalyst exhibited stable reactivity. 
After a slight deactivation in the first hour, stable $\mathrm{CO}_{2}$ and $\mathrm{H}_{2}$ formation was observed. This initial decrease in reactivity could be attributed to a depletion of available lattice oxygen atoms that react with $\mathrm{CO}$ to $\mathrm{CO}_{2}$. After this period, a steady state is reached, where re-oxidation of the lattice by oxygen from water splitting and the reaction of lattice oxygen with $\mathrm{CO}$ are in equilibrium. For Co-doped $\mathrm{Nd}_{0.6} \mathrm{Ca}_{0.4} \mathrm{Fe}_{0.9} \mathrm{Co}_{0.1} \mathrm{O}_{3-\delta}$, a slight increase in reactivity over time could be observed (Figure $7, \mathrm{CO}_{2}$ signal).

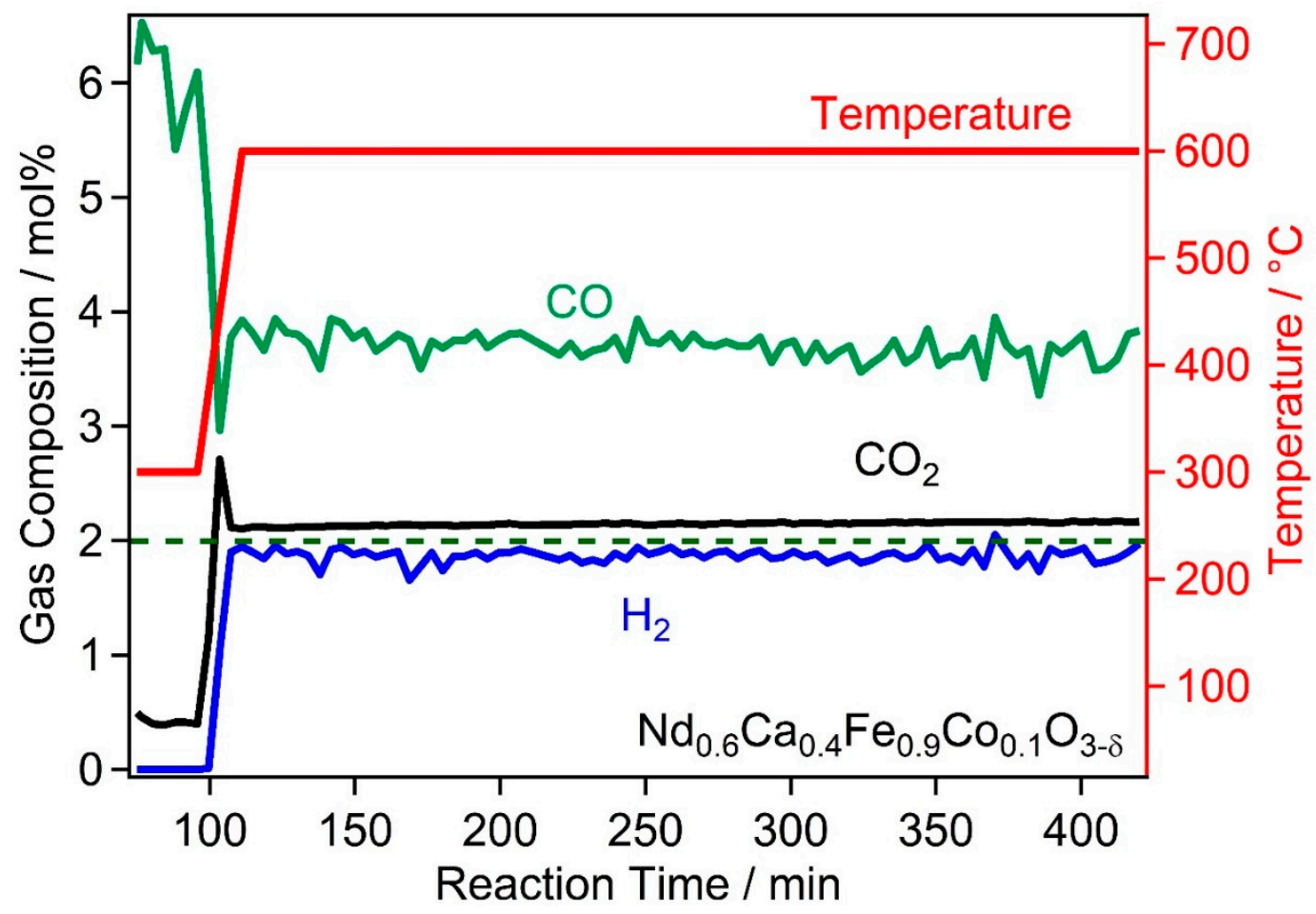

Figure 7. Isothermal HT-WGS reaction at $600{ }^{\circ} \mathrm{C}$ for $\mathrm{Nd}_{0.6} \mathrm{Ca}_{0.4} \mathrm{Fe}_{0.9} \mathrm{Co}_{0.1} \mathrm{O}_{3-\delta}$. The dashed line serves as a horizontal guide for the eye. During the duration of the reaction (about $5 \mathrm{~h}$ ), the catalyst was slightly increasing its reactivity.

This slight increase could be caused by a proceeding surface modification by still ongoing nanoparticle exsolution. To prove this, however, further long-term measurements would be needed. In conclusion, these results highlight that these novel materials are promising candidates for the further development of perovskite-based HT-WGS catalysts.

\section{Materials and Methods}

\subsection{Synthesis of Novel Perovskites}

As in previous work [24], the Pechini synthesis [65] was used to prepare the investigated perovskite powders. The following chemicals were used as starting materials to synthesise the materials with the wanted compositions: $\mathrm{La}\left(\mathrm{CH}_{3} \mathrm{COO}\right)_{3} \cdot 1.5 \mathrm{H}_{2} \mathrm{O}\left(99.9 \%\right.$, Alfa Aesar, Haverhill, MA, USA), $\mathrm{Nd}_{2} \mathrm{O}_{3}$ (99.9 \%, Strategic Elements, Deggendorf, Germany), $\mathrm{CaCO}_{3}$ (99.95 \%, Sigma-Aldrich, St. Louis, $\mathrm{MO}$, USA), Fe (99.5 \%, Sigma-Aldrich, St. Louis, $\mathrm{MO}, \mathrm{USA}), \mathrm{Co}\left(\mathrm{NO}_{3}\right)_{3} \cdot 6 \mathrm{H}_{2} \mathrm{O}(99.999 \%$, Sigma-Aldrich, St. Louis, $\mathrm{MO}, \mathrm{USA})$, and $\mathrm{Ni}\left(\mathrm{NO}_{3}\right)_{3} \cdot 6 \mathrm{H}_{2} \mathrm{O}(98 \%$, Alfa Aesar, Haverhill, MA, USA). Solutions of the appropriate amounts of the compounds were prepared in $\mathrm{HNO}_{3}$ (doubly distilled, 65\%, Merck, Darmstadt, Germany). Subsequent steps included the addition of citric acid (99.9998\% trace metals pure, Fluka, Honeywell International, Charlotte, NC, USA) in excess of $20 \%$ to form cation complexes, removing $\mathrm{H}_{2} \mathrm{O}$ by evaporation, and heating of the resulting gel until self-ignition. Then, the formed powders underwent heat treatment (calcination at $1350{ }^{\circ} \mathrm{C}$ for $3 \mathrm{~h}$ ) and were ground with a mortar to 
achieve homogeneity for better characterisation. The fine powder was then used for BET analysis and catalytic testing. The commercially available perovskite material $\mathrm{La}_{0.6} \mathrm{Sr}_{0.4} \mathrm{FeO}_{3-\delta}$ (LSF, Sigma Aldrich, St. Louis, MO, USA) was catalytically tested for comparison as well.

\subsection{Materials Characterisation}

Powder XRD measurements and SEM experiments were carried out as described by Lindenthal et al. [24]

The powder XRD measurements were done at room temperature in air on a PANalytical X'Pert Pro diffractometer (Malvern Panalytical, Malvern, UK) in Bragg-Brentano geometry using a mirror for separating the $\mathrm{Cu} \mathrm{K} \mathrm{K}_{\alpha 1,2}$ radiation and an X'Celerator linear detector (Malvern Panalytical, Malvern, UK). Data analysis was conducted with the HighScore Plus software (Malvern Panalytical, Malvern, UK) [66] and the PDF-4+ 2019 database (ICDD-International Centre for Diffraction Data, Newtown Square, PA, USA). [48] The database entries were used to ascribe the reflexes in the diffractograms.

The SEM images were recorded using secondary electrons on a Quanta 250 FEGSEM (FEI Company, Hillsboro, OR, USA) using an Octane Elite X-ray detector (EDAX Inc., Mahwah, NJ, USA) with an acceleration voltage of $5 \mathrm{kV}$ for sufficient surface-sensitivity. Additionally, specific surface areas were assessed according to the Brunauer-Emmet-Teller (BET) method by fitting measured adsorption isotherms to a BET model. The isotherms were recorded using a Micrometrics ASAP 2020 system. The samples were degassed at $300{ }^{\circ} \mathrm{C}$ under vacuum for $4 \mathrm{~h}$, followed by the measuring of full $\mathrm{N}_{2}$ adsorption-desorption isotherms at $-196^{\circ} \mathrm{C}$ (liquid $\mathrm{N}_{2}$ ).

\subsection{Catalytic Testing}

Similar to tests presented in [24], catalytic tests for HT-WGS reaction $\left(\mathrm{CO}+\mathrm{H}_{2} \mathrm{O} \leftrightarrow \mathrm{CO}_{2}+\mathrm{H}_{2}\right)$ were carried out in a tubular flow reactor (quartz glass, outer diameter $6 \mathrm{~mm}$, inner diameter $4 \mathrm{~mm}$ ) at atmospheric pressure. A Micro-GC (Fusion 3000A, Inficon, Bad Ragaz, Switzerland), taking a sample every 2-3 min was used for online gas analysis. The total flow was set to $12 \mathrm{~mL} \mathrm{~min}^{-1}$, with a CO flow of $0.70 \mathrm{~mL} \mathrm{~min}^{-1}$ and an Ar flow of $11.3 \mathrm{~mL} \mathrm{~min}^{-1}$ (all gases provided by Messer Group GmbH, Bad Soden, Germany). The Ar, which also acts as a carrier gas, was passed through a humidifier filled with water at room temperature. This leads to a $\mathrm{CO} / \mathrm{H}_{2} \mathrm{O}$ partial pressure of 1:1 in the educt gas flow. To assess the catalytic activity of the reactor, a run without catalyst was performed (resulting in an activity below $0.05 \mathrm{Mol} \%$ for $\mathrm{CO}_{2}$ at $600{ }^{\circ} \mathrm{C}$ ). The catalytic reactions were done with pure powder catalyst (50-70 mg) on a glass wool bed as support. The amounts of catalyst material for the respective experiments were chosen such that, during the reaction, the thermodynamic limit of the WGS reaction was not reached. The reactor heater was controlled by a PID controller (EMSR EUROTHERM GmbH, Vienna, Austria). To do so, a K-type thermocouple was reaching directly into the catalyst bed. Prior to all catalytic testing, each catalyst was oxidized for $30 \mathrm{~min}$ in $\mathrm{O}_{2}$ at $600{ }^{\circ} \mathrm{C}$ to ensure the same starting point for all materials (i.e., a fully oxidized perovskite).

To be able to directly compare the different perovskite catalysts, it was decided to calculate a specific activity. Usually, turnover frequencies (TOF) are given in the catalysis community, but this would require exact knowledge of the nature of an active site and also of the number of active sites on the surface. Perovskites are rather dynamic materials with a temperature (and reaction environment) dependent amount of vacancies that influence the nature of the surface reactivity. Different surface terminations are possible with different lattice elements (i.e., A- or B-cation, doping elements) exposed to the reaction environment. Furthermore, metal nanoparticle exsolution can occur (i.e., the formation of well-dispersed small metal nanoparticles on the surface) that enhances the reactivity and changes the number of active sites on the surface. Therefore, it is not scientifically sound to give a TOF value.

Instead, a specific activity $\left(\mathrm{mol} \mathrm{m}^{-2} \mathrm{~s}^{-1}\right)$ was calculated to directly compare the novel perovskite materials (which are all from a similar type). For this, the BET surface areas of the materials were measured (see Table 1). Using also the known amount of used catalyst material and the total gas flow, 
we normalized the $\mathrm{CO}_{2}$ formation to the catalyst surface area, giving a specific activity, i.e., how many mol of product (e.g., $\mathrm{CO}_{2}$ ) were formed per $\mathrm{m}^{2}$ surface and s.

\section{Conclusions}

It has been demonstrated that the novel perovskites are suitable catalyst materials for HT-WGS reactions. Whereas $\mathrm{La}_{0.9} \mathrm{Ca}_{0.1} \mathrm{FeO}_{3-\delta}$ and $\mathrm{La}_{0.6} \mathrm{Ca}_{0.4} \mathrm{FeO}_{3-\delta}$ show similar activity to the reference material LSF, changing the A-site cation from La to $\mathrm{Nd}$ significantly increased the catalytic reactivity of the perovskites. At $600{ }^{\circ} \mathrm{C}$, the specific activity of $\mathrm{Nd}_{0.9} \mathrm{Ca}_{0.1} \mathrm{FeO}_{3-\delta}\left(18.7 \cdot 10^{-7} \mathrm{~mol} \mathrm{~m}^{-2} \mathrm{~s}^{-1}\right)$ was roughly three times higher than for $\mathrm{La}_{0.9} \mathrm{Ca}_{0.1} \mathrm{FeO}_{3-\delta}\left(5.7 \cdot 10^{-7} \mathrm{~mol} \mathrm{~m}^{-2} \mathrm{~s}^{-1}\right)$. Furthermore, the B-site of the perovskite was doped with catalytically highly active $\mathrm{Ni}$ or $\mathrm{Co}$. Ni doping was not fully successful, as not all $\mathrm{Ni}$ could be incorporated in the perovskite lattice and trace amounts of $\mathrm{NiO}$ were observed in the XRD pattern. In contrast, Co doping was successful, leading to phase pure $\mathrm{Nd}_{0.6} \mathrm{Ca}_{0.4} \mathrm{Fe}_{0.9} \mathrm{Co}_{0.1} \mathrm{O}_{3-\delta}$. The $\mathrm{Co}$ - and Ni-doped perovskites exhibited the highest HT-WGS reactivity at $600{ }^{\circ} \mathrm{C}$, with specific activities of $28.4 \cdot 10^{-7}$ and $36.9 \cdot 10^{-7} \mathrm{~mol} \mathrm{~m}^{-2} \mathrm{~s}^{-1}$ respectively. Additionally, the formation of nanoparticles on the surface by exsolution could be observed during reaction. The stability of the novel materials over longer periods of time was also tested, showing that all materials did not deactivate over the whole duration of the test.

The WGS activity is discussed to be improved by two factors: first, the kinetics of CO oxidation, which proceeds on the oxide surface and is enhanced by an increased redox activity of the oxide (e.g., by using $\mathrm{Nd}$ instead of La as A-site cation). Second, the water-splitting kinetics can be accelerated by providing metallic particles on the catalyst surface. This can be achieved by doping the B-site of the perovskite with easily reducible cations (e.g., $\mathrm{Co}$ or $\mathrm{Ni}$ ) that exsolve under reaction conditions. Therefore, perovskites are an ideal material class to handle this "job sharing"—perovskite backbone for $\mathrm{CO}$ oxidation and exsolved nanoparticles for water splitting - and to optimize both reactions at the same time. Furthermore, their properties are easily adjustable—by choosing the elemental composition of A- and B-site, introducing doping and varying stoichiometry. Our results highlight that doped perovskites are promising candidates for the further development of novel HT-WGS catalysts and provide all the tools needed for high activity and stable operation.

Supplementary Materials: The following figures are available online at http://www.mdpi.com/2073-4344/10/5/ 582/s1, Figure S1: thermodynamic limitation of the WGS reaction and reaction equilibrium; Figure S2: SEM images of $\mathrm{Nd}_{0.6} \mathrm{Ca}_{0.4} \mathrm{Fe}_{0.9} \mathrm{Ni}_{0.1} \mathrm{O}_{3-\delta}$ and $\mathrm{Nd}_{0.9} \mathrm{Ca}_{0.1} \mathrm{FeO}_{3-\delta}$ prior to reaction; Figures S3-S7: Stability tests for WGS reaction on $\mathrm{La}_{0.9} \mathrm{Ca}_{0.1} \mathrm{FeO}_{3-\delta}, \mathrm{La}_{0.6} \mathrm{Ca}_{0.4} \mathrm{FeO}_{3-\delta}, \mathrm{Nd}_{0.9} \mathrm{Ca}_{0.1} \mathrm{FeO}_{3-\delta}, \mathrm{Nd}_{0.6} \mathrm{Ca}_{0.4} \mathrm{Fe}_{0.9} \mathrm{Ni}_{0.1} \mathrm{O}_{3-\delta}$, and LSF.

Author Contributions: Conceptualization: C.R.; Validation: L.L., R.R., J.P., A.N., and S.L.; Formal analysis: L.L., J.P., and T.R.; Investigation: L.L., R.R., J.P., and S.L.; Resources: L.L.; Data curation: L.L., R.R., J.P., and T.R.; Writing-original draft preparation: C.R.; Writing-review and editing: C.R., A.K.O., A.N., L.L. and T.R.; Visualization: L.L., T.R. and R.R.; Supervision: C.R.; Project administration: C.R.; Funding acquisition: C.R. All authors have read and agreed to the published version of the manuscript.

Funding: This research was funded by the European Research Council (ERC) under the European Union's Horizon 2020 research and innovation programme, grant agreement no. 755744/ERC—Starting Grant TUCAS.

Conflicts of Interest: The authors declare no conflict of interest.

\section{References}

1. Zhu, M.H.; Wachs, I.E. Iron-Based Catalysts for the High-Temperature Water Gas Shift (HT-WGS) Reaction: A Review. ACS Catal. 2016, 6, 722-732. [CrossRef]

2. LeValley, T.L.; Richard, A.R.; Fan, M.H. The progress in water gas shift and steam reforming hydrogen production technologies-A review. Int. J. Hydrog. Energy 2014, 39, 16983-17000. [CrossRef]

3. Chen, C.C.; Tseng, H.H.; Lin, Y.L.; Chen, W.H. Hydrogen production and carbon dioxide enrichment from ethanol steam reforming followed by water gas shift reaction. J. Clean. Prod. 2017, 162, 1430-1441. [CrossRef]

4. Hosseini, S.E.; Wahid, M.A. Hydrogen production from renewable and sustainable energy resources: Promising green energy carrier for clean development. Renew. Sustain. Energy Rev. 2016, 57, 850-866. [CrossRef] 
5. Guczi, L.; Stefler, G.; Geszti, O.; Sajo, I.; Paszti, Z.; Tompos, A.; Schay, Z. Methane dry reforming with $\mathrm{CO}_{2}$ : A study on surface carbon species. Appl. Catal. A Gen. 2010, 375, 236-246. [CrossRef]

6. Bukur, D.B.; Todic, B.; Elbashir, N. Role of water-gas-shift reaction in Fischer-Tropsch synthesis on iron catalysts: A review. Catal. Today 2016, 275, 66-75. [CrossRef]

7. Zhu, M.H.; Tian, P.F.; Kurtz, R.; Lunkenbein, T.; Xu, J.; Schlogl, R.; Wachs, I.E.; Han, Y.F. Strong Metal-Support Interactions between Copper and Iron Oxide during the High-Temperature Water-Gas Shift Reaction. Angew. Chem. Int. Ed. 2019, 58, 9083-9087. [CrossRef]

8. Polo-Garzon, F.; Fung, V.; Nguyen, L.; Tang, Y.; Tao, F.; Cheng, Y.Q.; Daemen, L.L.; Ramirez-Cuesta, A.J.; Foo, G.S.; Zhu, M.H.; et al. Elucidation of the Reaction Mechanism for High-Temperature Water Gas Shift over an Industrial-Type Copper-Chromium-Iron Oxide Catalyst. J. Am. Chem. Soc. 2019, 141, 7990-7999. [CrossRef]

9. Pastor-Perez, L.; Gu, S.; Sepulveda-Escribano, A.; Reina, T.R. Bimetallic Cu-Ni catalysts for the WGS reaction-Cooperative or uncooperative effect? Int. J. Hydrog. Energy 2019, 44, 4011-4019. [CrossRef]

10. Liu, N.; Xu, M.; Yang, Y.S.; Zhang, S.M.; Zhang, J.; Wang, W.L.; Zheng, L.R.; Hong, S.; Wei, M. Au ${ }^{\delta-}-\mathrm{O}_{\mathrm{v}}-\mathrm{Ti}^{3+}$ Interfacial Site: Catalytic Active Center toward Low-Temperature Water Gas Shift Reaction. ACS Catal. 2019, 9, 2707-2717. [CrossRef]

11. Pal, D.B.; Chand, R.; Upadhyay, S.N.; Mishra, P.K. Performance of water gas shift reaction catalysts: A review. Renew. Sustain. Energy Rev. 2018, 93, 549-565. [CrossRef]

12. Ovesen, C.V.; Stoltze, P.; Norskov, J.K.; Campbell, C.T. A Kinetic-Model of the Water Gas Shift Reaction. J. Catal. 1992, 134, 445-468. [CrossRef]

13. Koryabkina, N.A.; Phatak, A.A.; Ruettinger, W.F.; Farrauto, R.J.; Ribeiro, F.H. Determination of kinetic parameters for the water-gas shift reaction on copper catalysts under realistic conditions for fuel cell applications. J. Catal. 2003, 217, 233-239. [CrossRef]

14. Rhodes, C.; Williams, B.P.; King, F.; Hutchings, G.J. Promotion of $\mathrm{Fe}_{3} \mathrm{O}_{4} / \mathrm{Cr}_{2} \mathrm{O}_{3}$ high temperature water gas shift catalyst. Catal. Commun. 2002, 3, 381-384. [CrossRef]

15. Lee, D.W.; Lee, M.S.; Lee, J.Y.; Kim, S.; Eom, H.J.; Moon, D.J.; Lee, K.Y. The review of Cr-free Fe-based catalysts for high-temperature water-gas shift reactions. Catal. Today 2013, 210, 2-9. [CrossRef]

16. Liu, B.N.; Zhao, L.; Wu, Z.J.; Zhang, J.; Zong, Q.Y.; Almegren, H.; Wei, F.; Zhang, X.H.; Zhao, Z.; Gao, J.S.; et al. Recent Advances in Industrial Sulfur Tolerant Water Gas Shift Catalysts for Syngas Hydrogen Enrichment: Application of Lean (Low) Steam/Gas Ratio. Catalysts 2019, 9. [CrossRef]

17. Jeong, D.W.; Jang, W.J.; Shim, J.O.; Han, W.B.; Roh, H.S.; Jung, U.H.; Yoon, W.L. Low-temperature water-gas shift reaction over supported Cu catalysts. Renew. Energy 2014, 65, 102-107. [CrossRef]

18. Damma, D.; Smirniotis, P.G. Recent advances in iron-based high-temperature water-gas shift catalysis for hydrogen production. Curr. Opin. Chem. Eng. 2018, 21, 103-110. [CrossRef]

19. Damma, D.; Boningari, T.; Smirniotis, P.G. High-temperature water-gas shift over Fe/Ce/Co spinel catalysts: Study of the promotional effect of Ce and Co. Mol. Catal. 2018, 451, 20-32. [CrossRef]

20. Oemar, U.; Bian, Z.; Hidajat, K.; Kawi, S. Sulfur resistant $\mathrm{La}_{x} \mathrm{Ce}_{1-\mathrm{x}} \mathrm{Ni}_{0.5} \mathrm{Cu}_{0.5} \mathrm{O}_{3}$ catalysts for an ultra-high temperature water gas shift reaction. Catal. Sci. Technol. 2016, 6, 6569-6580. [CrossRef]

21. Saw, E.T.; Oemar, U.; Tan, X.R.; Du, Y.; Borgna, A.; Hidajat, K.; Kawi, S. Bimetallic Ni-Cu catalyst supported on $\mathrm{CeO}_{2}$ for high-temperature water-gas shift reaction: Methane suppression via enhanced $\mathrm{CO}$ adsorption. J. Catal. 2014, 314, 32-46. [CrossRef]

22. Roh, H.S.; Potdar, H.S.; Jeong, D.W.; Kim, K.S.; Shim, J.O.; Jang, W.J.; Koo, K.Y.; Yoon, W.L. Synthesis of highly active nano-sized $\left(1 \mathrm{wt} \% \mathrm{Pt} / \mathrm{CeO}_{2}\right)$ catalyst for water gas shift reaction in medium temperature application. Catal. Today 2012, 185, 113-118. [CrossRef]

23. Buitrago, R.; Ruiz-Martinez, J.; Silvestre-Albero, J.; Sepulveda-Escribano, A.; Rodriguez-Reinoso, F. Water gas shift reaction on carbon-supported Pt catalysts promoted by $\mathrm{CeO}_{2}$. Catal. Today 2012, 180, 19-24. [CrossRef]

24. Lindenthal, L.; Rameshan, R.; Summerer, H.; Ruh, T.; Popovic, J.; Nenning, A.; Löffler, S.; Opitz, A.K.; Blaha, P.; Rameshan, C. Modifying the Surface Structure of Perovskite-Based Catalysts by Nanoparticle Exsolution. Catalysts 2020, 10, 268. [CrossRef]

25. Sun, Y.; Hla, S.S.; Duffy, G.J.; Cousins, A.J.; French, D.; Morpeth, L.D.; Edwards, J.H.; Roberts, D.G. Effect of $\mathrm{Ce}$ on the structural features and catalytic properties of $\mathrm{La}_{(0.9-\mathrm{x})} \mathrm{Ce}_{\mathrm{x}} \mathrm{FeO}_{3}$ perovskite-like catalysts for the high temperature water-gas shift reaction. Int. J. Hydrog. Energy 2011, 36, 79-86. [CrossRef] 
26. Maluf, S.S.; Nascente, P.A.P.; Afonso, C.R.M.; Assaf, E.M. Study of $\mathrm{La}_{2-x} \mathrm{Ca}_{x} \mathrm{CuO}_{4}$ perovskites for the low temperature water gas shift reaction. Appl. Catal. A Gen. 2012, 413, 85-93. [CrossRef]

27. Hwang, J.; Rao, R.R.; Giordano, L.; Katayama, Y.; Yu, Y.; Shao-Horn, Y. Perovskites in catalysis and electrocatalysis. Science 2017, 358, 751-756. [CrossRef]

28. Nishihata, Y.; Mizuki, J.; Akao, T.; Tanaka, H.; Uenishi, M.; Kimura, M.; Okamoto, T.; Hamada, N. Self-regeneration of a Pd-perovskite catalyst for automotive emissions control. Nature 2002, 418, 164-167. [CrossRef]

29. Shin, T.H.; Myung, J.H.; Verbraeken, M.; Kim, G.; Irvine, J.T.S. Oxygen deficient layered double perovskite as an active cathode for $\mathrm{CO}_{2}$ electrolysis using a solid oxide conductor. Faraday Discuss. 2015, 182, 227-239. [CrossRef]

30. Stöger, B.; Hieckel, M.; Mittendorfer, F.; Wang, Z.M.; Fobes, D.; Peng, J.; Mao, Z.Q.; Schmid, M.; Redinger, J.; Diebold, U. High Chemical Activity of a Perovskite Surface: Reaction of CO with $\mathrm{Sr}_{3} \mathrm{Ru}_{2} \mathrm{O}_{7}$. Phys. Rev. Lett. 2014, 113. [CrossRef]

31. Katz, M.B.; Zhang, S.Y.; Duan, Y.W.; Wang, H.J.; Fang, M.H.; Zhang, K.; Li, B.H.; Graham, G.W.; Pan, X.Q. Reversible precipitation/dissolution of precious-metal clusters in perovskite-based catalyst materials: Bulk versus surface re-dispersion. J. Catal. 2012, 293, 145-148. [CrossRef]

32. Thalinger, R.; Opitz, A.K.; Kogler, S.; Heggen, M.; Stroppa, D.; Schmidmair, D.; Tappert, R.; Fleig, J.; Klotzer, B.; Penner, S. Water-Gas Shift and Methane Reactivity on Reducible Perovskite-Type Oxides. J. Phys. Chem. C 2015, 119, 11739-11753. [CrossRef] [PubMed]

33. Mueller, D.N.; Machala, M.L.; Bluhm, H.; Chueh, W.C. Redox activity of surface oxygen anions in oxygen-deficient perovskite oxides during electrochemical reactions. Nat. Commun. 2015, 6. [CrossRef] [PubMed]

34. Wheeler, C.; Jhalani, A.; Klein, E.J.; Tummala, S.; Schmidt, L.D. The water-gas-shift reaction at short contact times. J. Catal. 2004, 223, 191-199. [CrossRef]

35. Wang, X.Q.; Rodriguez, J.A.; Hanson, J.C.; Gamarra, D.; Martinez-Arias, A.; Fernandez-Garcia, M. In situ studies of the active sites for the water gas shift reaction over $\mathrm{Cu}-\mathrm{CeO}_{2}$ catalysts: Complex interaction between metallic copper and oxygen vacancies of ceria. J. Phys. Chem. B 2006, 110, 428-434. [CrossRef]

36. Gibbons, W.T.; Liu, T.H.; Gaskell, K.J.; Jackson, G.S. Characterization of palladium/copper/ceria electrospun fibers for water-gas shift catalysis. Appl. Catal. B Environ. 2014, 160, 465-479. [CrossRef]

37. Keiski, R.L.; Salmi, T.; Niemisto, P.; Ainassaari, J.; Pohjola, V.J. Stationary and transient kinetics of the high temperature water-gas shift reaction. Appl. Catal. A Gen. 1996, 137, 349-370. [CrossRef]

38. Natesakhawat, S.; Wang, X.Q.; Zhang, L.Z.; Ozkan, U.S. Development of chromium-free iron-based catalysts for high-temperature water-gas shift reaction. J. Mol. Catal. A Chem. 2006, 260, 82-94. [CrossRef]

39. Nagai, M.; Matsuda, K. Low-temperature water-gas shift reaction over cobalt-molybdenum carbide catalyst. J. Catal. 2006, 238, 489-496. [CrossRef]

40. Neagu, D.; Oh, T.S.; Miller, D.N.; Menard, H.; Bukhari, S.M.; Gamble, S.R.; Gorte, R.J.; Vohs, J.M.; Irvine, J.T.S. Nano-socketed nickel particles with enhanced coking resistance grown in situ by redox exsolution. Nat. Commun. 2015, 6. [CrossRef]

41. Oh, T.S.; Rahani, E.K.; Neagu, D.; Irvine, J.T.S.; Shenoy, V.B.; Gorte, R.J.; Vohs, J.M. Evidence and Model for Strain-Driven Release of Metal Nanocatalysts from Perovskites during Exsolution. J. Phys. Chem. Lett. 2015, 6, 5106-5110. [CrossRef] [PubMed]

42. Neagu, D.; Tsekouras, G.; Miller, D.N.; Menard, H.; Irvine, J.T.S. In situ growth of nanoparticles through control of non-stoichiometry. Nat. Chem. 2013, 5, 916-923. [CrossRef] [PubMed]

43. Lee, W.; Han, J.W.; Chen, Y.; Cai, Z.; Yildiz, B. Cation Size Mismatch and Charge Interactions Drive Dopant Segregation at the Surfaces of Manganite Perovskites. J. Am. Chem. Soc. 2013, 135, 7909-7925. [CrossRef] [PubMed]

44. Geller, S. Crystallographic Studies of Perovskite-like Compounds V: Relative Ionic Sizes. Acta Crystallogr. 1957, 10, 248-251. [CrossRef]

45. Nenning, A.; Opitz, A.K.; Rameshan, C.; Rameshan, R.; Blume, R.; Haevecker, M.; Knop-Gericke, A.; Rupprechter, G.; Kloetzer, B.; Fleigt, J. Ambient Pressure XPS Study of Mixed Conducting Perovskite-Type SOFC Cathode and Anode Materials under Well-Defined Electrochemical Polarization. J. Phys. Chem. C 2016, 120, 1461-1471. [CrossRef] 
46. Lorenz, H.; Zhao, Q.A.; Turner, S.; Lebedev, O.I.; van Tendeloo, G.; Klotzer, B.; Rameshan, C.; Penner, S. Preparation and structural characterization of $\mathrm{SnO}_{2}$ and $\mathrm{GeO}_{2}$ methanol steam reforming thin film model catalysts by (HR) TEM. Mater. Chem. Phys. 2010, 122, 623-629. [CrossRef]

47. Brunauer, S.; Emmett, P.H.; Teller, E. Adsorption of gases in multimolecular layers. J. Am. Chem. Soc. 1938, 60, 309-319. [CrossRef]

48. ICDD. PDF-4 + 2019; Kabekkodu, S., Ed.; International Centre for Diffraction Data: Newtown Square, PA, USA, 2018.

49. Yablonsky, G.S.; Pilasombat, R.; Breen, J.P.; Burch, R.; Hengrasmee, S. Cycles Across an Equilibrium: A Kinetic Investigation of the Reverse and Forward WGS Reaction over a $\% \mathrm{Pt} / \mathrm{CeO}_{2}$ Catalyst (Experimental Data and Qualitative Interpretation). Chem. Eng. Sci. 2010, 65, 2325-2332. [CrossRef]

50. Kuhn, M.; Hashimoto, S.; Sato, K.; Yashiro, K.; Mizusaki, J. Oxygen nonstoichiometry, thermo-chemical stability and lattice expansion of $\mathrm{La}_{0.6} \mathrm{Sr}_{0.4} \mathrm{FeO}_{3-\delta}$. Solid State Ion. 2011, 195, 7-15. [CrossRef]

51. Opitz, A.K.; Nenning, A.; Rameshan, C.; Rameshan, R.; Blume, R.; Haevecker, M.; Knop-Gericke, A.; Rupprechter, G.; Fleig, J.; Kloetzer, B. Enhancing Electrochemical Water-Splitting Kinetics by PolarizationDriven Formation of Near-Surface Iron (0): An In Situ XPS Study on Perovskite-Type Electrodes. Angew. Chem. Int. Ed. 2015, 54, 2628-2632. [CrossRef]

52. Kuhn, M.; Fukuda, Y.; Hashimoto, S.; Sato, K.; Yashiro, K.; Mizusaki, J. Oxygen Nonstoichiometry and Thermo-Chemical Stability of Perovskite-Type $\mathrm{La}_{0.6} \mathrm{Sr}_{0.4} \mathrm{Co}_{1-\mathrm{y}} \mathrm{Fe}_{\mathrm{y}} \mathrm{O}_{3-\delta}(\mathrm{y}=0,0.2,0.4,0.5,0.6,0.8,1)$ Materials. J. Electrochem. Soc. 2013, 160, F34-F42. [CrossRef]

53. Dutta, G.; Waghmare, U.V.; Baidya, T.; Hegde, M.S.; Priolkar, K.R.; Sarode, P.R. Reducibility of $\mathrm{Ce}_{1-\mathrm{x}} \mathrm{Zr}_{\mathrm{x}} \mathrm{O}_{2}$ : Origin of enhanced oxygen storage capacity. Catal. Lett. 2006, 108, 165-172. [CrossRef]

54. Opitz, A.K.; Nenning, A.; Rameshan, C.; Kubicek, M.; Goetsch, T.; Blume, R.; Haevecker, M.; Knop-Gericke, A.; Rupprechter, G.; Kloetzer, B.; et al. Surface Chemistry of Perovskite-Type Electrodes During High Temperature $\mathrm{CO}_{2}$ Electrolysis Investigated by Operando Photoelectron Spectroscopy. ACS Appl. Mater. Interfaces 2017, 9 , 35847-35860. [CrossRef]

55. Hwang, J.; Rao, R.R.; Katayama, Y.; Lee, D.; Wang, X.R.; Crumlin, E.; Venkatesan, T.; Lee, H.N.; Shao-Horn, Y. $\mathrm{CO}_{2}$ Reactivity on Cobalt-Based Perovskites. J. Phys. Chem. C 2018, 122, 20391-20401. [CrossRef]

56. Wu, X.Y.; Ghoniem, A.F. Hydrogen-assisted Carbon Dioxide Thermochemical Reduction on $\mathrm{La}_{0.9} \mathrm{Ca}_{0.1} \mathrm{FeO}_{3-\delta}$ Membranes: A Kinetics Study. Chemsuschem 2018, 11, 483-493. [CrossRef] [PubMed]

57. Dimitrakopoulos, G.; Ghoniem, A.F. Developing a multistep surface reaction mechanism to model the impact of $\mathrm{H}-2$ and $\mathrm{CO}$ on the performance and defect chemistry of $\mathrm{La}_{0.9} \mathrm{Ca}_{0.1} \mathrm{FeO}_{3-\delta}$ mixed-conductors. J. Membr. Sci. 2017, 529, 114-132. [CrossRef]

58. Shen, P.J.; Ding, W.Z.; Zhou, Y.D.; Huang, S.Q. Reaction mechanism on reduction surface of mixed conductor membrane for $\mathrm{H}_{2}$ production by coal-gas. Appl. Surf. Sci. 2010, 256, 5094-5101. [CrossRef]

59. Dimitrakopoulos, G.; Ghoniem, A.F.; Yildiz, B. In situ catalyst exsolution on perovskite oxides for the production of CO and synthesis gas in ceramic membrane reactors. Sustain. Energy Fuels 2019, 3, 2347-2355. [CrossRef]

60. Zhu, T.L.; Fowler, D.E.; Poeppelmeier, K.R.; Han, M.F.; Barnett, S.A. Hydrogen Oxidation Mechanisms on Perovskite Solid Oxide Fuel Cell Anodes. J. Electrochem. Soc. 2016, 163, F952-F961. [CrossRef]

61. Koo, B.; Kim, K.; Kim, J.K.; Kwon, H.; Han, J.W.; Jung, W. Sr Segregation in Perovskite Oxides: Why It Happens and How It Exists. Joule 2018, 2, 1476-1499. [CrossRef]

62. Rupp, G.M.; Limbeck, A.; Kubicek, M.; Penn, A.; Stoger-Pollach, M.; Friedbacher, G.; Fleig, J. Correlating surface cation composition and thin film microstructure with the electrochemical performance of lanthanum strontium cobaltite (LSC) electrodes. J. Mater. Chem. A 2014, 2, 7099-7108. [CrossRef]

63. Rupp, G.M.; Opitz, A.K.; Nenning, A.; Limbeck, A.; Fleig, J. Real-time impedance monitoring of oxygen reduction during surface modification of thin film cathodes. Nat. Mater. 2017, 16, 640-645. [CrossRef] [PubMed]

64. Tsekouras, G.; Neagu, D.; Irvine, J.T.S. Step-change in high temperature steam electrolysis performance of perovskite oxide cathodes with exsolution of B-site dopants. Energy Environ. Sci. 2013, 6, 256-266. [CrossRef] 
65. Pechini, M.P. Method of Preparing Lead and Alkaline Earth Titanates and Niobates and Coating Method Using the Same to Form a Capacitor. U.S. Patent 3,330,697, 11 July 1967.

66. Degen, T.; Sadki, M.; Bron, E.; König, U.; Nénert, G. The HighScore suite. Powder Diffr. 2014, 29, S13-S18. [CrossRef]

(c) (C) 2020 by the authors. Licensee MDPI, Basel, Switzerland. This article is an open access article distributed under the terms and conditions of the Creative Commons Attribution (CC BY) license (http://creativecommons.org/licenses/by/4.0/). 